\title{
Identification of Site Specific Diatom at Yamuna River of Allahabad
}

\author{
Garima Yadav, M.K. Mishra, A. K. Gupta, Shailesh \\ Department of Forensic Science, Faculty of Science, Sam Higginbottom Institute of Agriculture Technology and \\ Sciences, Allahabad, Uttar Pradesh, India
}

\begin{abstract}
In present study water sample from four sites of Yamuna River were collected for identification of diatom. Collected water sample were digested with acid digestion and examined under high power microscope after slide preparation. After examination it was found that total 41 diatom species was found at four sites of river. Out of 41 diatom species 10 diatom species were found as site specific. These site specific diatoms can be used as marker for site identification in cases of suspected drowning as well as for other forensic purposes.
\end{abstract}

\section{Introduction:}

Diatoms are microscopic unicellular eukaryotic organisms ranging in size from approximately 5 microns to 1000 microns and of the most common types of phytoplankton. The word 'diatom' means 'cut in two' and is derived from the Greek :(dia) = 'through' + (temnein) = 'to cut', i.e. 'cut in half'. A characteristic feature of diatoms cell is that they are encased within a cell wall made of silica (hydrated silicon dioxide) called a Frustule and is found in almost aquatic environment including fresh and marine waters, soils, in fact almost anywhere in moist environment. There are more than 200 genera of living diatoms and it is estimated that there are approximately 100,000 extant species (Hasle et al., 1997), either free-floating, planktonic forms or attached to substrate. Diatoms grow as single cells, or form simple filaments/colonies. They form the base of aquatic food webs in marine and fresh water habitats. Diatoms are divided into two orders. The Centrales (now called the Biddulphiales) which have valve striae arranged basically in relation to a point, an annulus or a centrals areola and tend to appear radially symmetrical, and the Pennales (now called Bacillariales) which have valve striae arranged in relation to a line and tend to appear bilaterally symmetrical. The valve face of diatom frustules is ornamented with pores (areolae),spines, hyaline areas and other distinguishing morphological features. It is these skeletal features, which are used to classify and describe diatoms, which is an advantage in terms of paleontology since the same features are used to define extant species as extinct ones. Diatoms have several as a unique forensic marker in deciding the cause of death as drowning and in solving drowning related cases where medical officers fail ascertain the cause of death especially in cases when skeletonised and putrefied dead bodies are recovered.

\section{Methodology:}

$500 \mathrm{ml}$ to $1000 \mathrm{ml}$ water sample were collected in thoroughly washed bottle and then bottles were tightly fitted with cap \& labelled with the location of sampling site, along with the date, time, and month. Water samples were collected at the bank, mid \& across the river. Water samples were collected in different month continuously at month February to May . The water samples were collected from 4-different sites [Site1 (old bridge), Site2 (new bridge), Site3 (boat club) and Site4 (Sangam)] of Yamuna River at Allahabad. The collected water samples were brought to the laboratory for examination of diatoms. $500 \mathrm{ml}$ water sample was taken into the beaker from each bottles and $10 \mathrm{ml}$ of Lugol's iodine was added in beaker .Lugol's iodine was used as preservative of water sample and left it for overnight. According to Ludes et al., (1996), 50ml of Conc. $\mathrm{HNO}_{3}$, $\mathrm{KMnO}_{4} \& \mathrm{H}_{2} \mathrm{O}_{2}$ was added in $500 \mathrm{ml}$ water sample in 5:2:3 ratios. They oxidize the organic matter present in the water sample except diatom cell wall because cell wall is resistant to them.

The next day samples were taken in Tarson tubes \& centrifuged at 1500rpm for 5-7 minutes and the supernant were discarded. This step was repeated till full of the water sample contained in the beaker was centrifuged.

The Pellets were formed at the bottom of Tarson tube, the pellets were taken with the dropper and transferred on microscopic slide, left it for drying on the hot plate and cover it with cover slip then observed under compound microscope at 10x ,45x and 100x (oil immersion) magnification Taylor et al.,(2007). The same steps were repeated for all the samples from sites $S_{1}$ to $S_{4}$ for morphological examination of diatoms.

\section{Result And Discussion:}

Different diatoms were identified by using standard International literature (Metzeltin et al., 2005) for identification. Their characteristics features such as Raphea, cell wall diameter, shape were examined for their 
identification. 41 diatoms species were identified at different four sites of Yamuna River at Allahabad. Out of 41 diatoms species, 24 diatoms species were identified at site-1 of Yamuna River except these-

Two site specific diatom species were identified at site S1 i.e. Cymbella hustedii, Surirella tenera. fig.1.

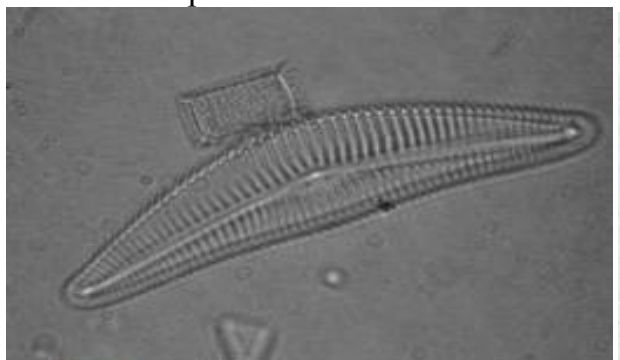

Cymbella hustedii

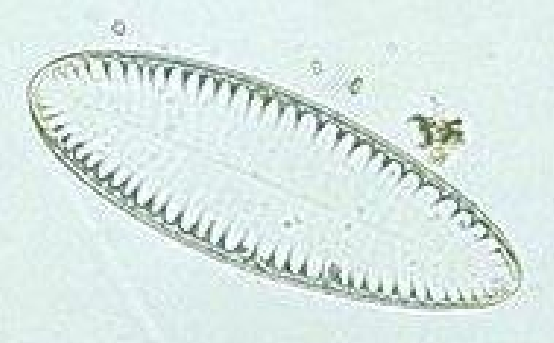

Surirella tenera

Fig.1

Two site specific diatom were identified at site S2 i.e. Gomphonema intermedium and Synedra affins. fig.2

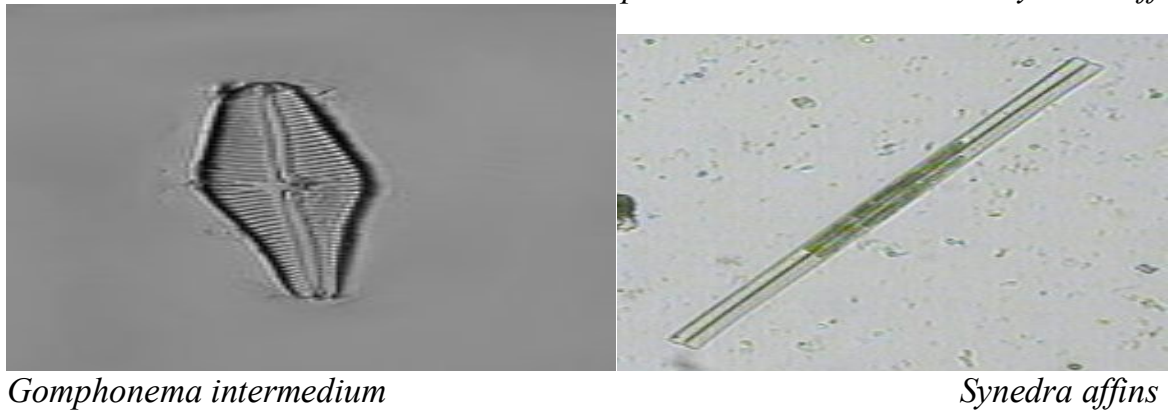

Fig. 2

Two site specific diatom species were identified at site S3 i.e. Pinnularia acrosphaeria \& P.gibba fig.3.

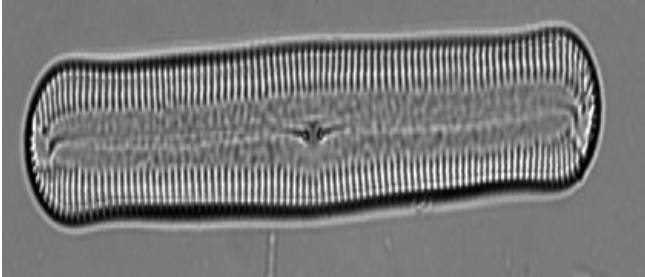

Pinnularia acrosphaeria

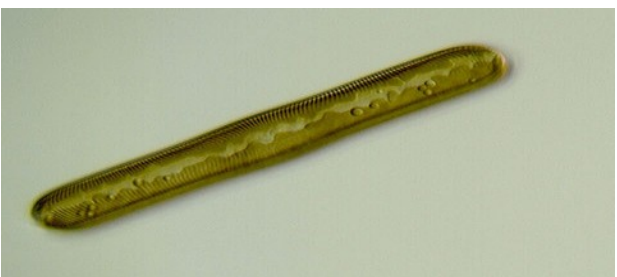

P.gibba

Fig.3

Three site specific diatom species were identified at site S4 i.e. Pinnularia interrupta, Rhopalodia brebissonii \& N.chandolensis.fig.4.

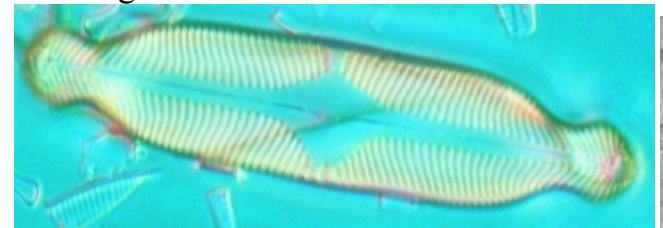

Pinnularia interrupta

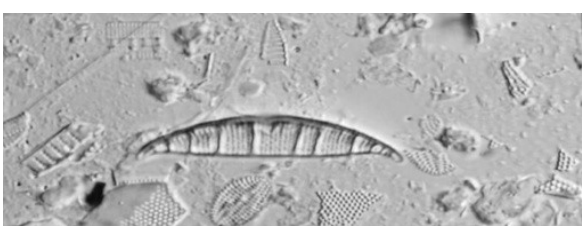

Rhopalodia brebissonii

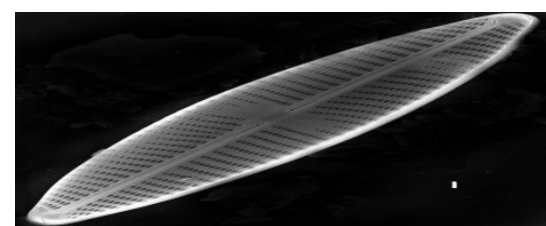

N.chandolensis

IV. Discussion:

Diatoms were identified by using standard International literature (Metzeltin et al., 2005) for identification. The result for the study is accordance with the work performed earlier by the scientist Tiwari $\boldsymbol{e t}$ al., (2006) reported 21 diatoms species in Allahabad locality.

41 diatoms species have been identified after extraction and isolation by acid digestion method from four sites i.e. S1, S2, S3 \& S4. At site-1, 24 diatoms species were identified. Out of 24 diatoms species, 22 
diatoms species were common at the site- 1 and site-2 specific diatoms species were identified at site S1 i.e. Cymbella hustedii, Surirella tenera. At site2, 24 diatom species were also identified. Out of 24 diatom species, site-2, specific diatom species were identified at site-2 i.e. (G. intermedium and Synedra affins) and 22 diatom species were common at site2. At site3, 24 diatoms were identified. Out of 24 diatom species, 2 site specific diatom species were identified at Site S3 i.e.Pinnularia acrosphaeria \& P.gibba and 22 diatom species were common at site 3. At site 4, 27 diatom species were identified. Out of 27 diatoms, 3 site specific diatoms were identified at siteS4 i.e. Pinnularia interrupta,Rhopalodia brebissonii \& N.chandolensis and 24 common diatom species were identified at sub sites of site 4 .

\section{Summary And Conclusion}

In present study, 145 water samples were collected during the month of February to May 2013 from Yamuna River \& coherent Sangam sites. After collection of water sample, all were brought to the laboratory for the analysis of Diatoms. The collected water samples were preserved by adding Lugol's Iodine \& kept overnight. After that, Diatoms from the collected water sample were extracted as per the method prescribed by Ludes et al. (1996). In this process, $50 \mathrm{ml}$ of digesting reagent (Conc. Nitric acid, potassium permanganate, hydrogen peroxide) in 5:2:3 ratio were mixed in $500 \mathrm{ml}$ of water sample. Until the pellets formation in Tarson tube, centrifugation was continued. After pellets formation, the pellets were transferred on slide \& thin layer was prepared. After that, microscopical examination was done at 10x \& 45x magnification for identification of the diatom species at the corresponding sites. After examination \& identification by slide preparation,at site 1, 24 diatom species were identified such as Amphora ovalis, A.rugosa, A.venta, C.cymbiformis, C.placentula var. lineate, Cocconeis pediculus, Craticula halophila, Cyclotella operculata, Cymatopleura solea, Diatoma vulgaris, E. tschirchiana, F.intermedia, Fragilaria capucina, G.intermedium, Gomphoema acuminatum, N.gottlandica, N.radiosa, Pinnularia acrosphaeria, P.gibba, Surirella elegans, Synedra affins, Cymbella hustedii, Surirella tenera. Out of 24 diatom species, 2 site specific diatom species were identified at site1 i.e. Cymbella hustedii, Surirella tenera.

At site2, 24 diatom species were also identified such as Amphora ovalis ,A.rugosa, A.venta, C.cymbiformis, C.placentula var. lineate, Cocconeis pediculus, Craticula halophila, Cyclotella operculata, Cymatopleura solea, Diatoma vulgaris, E. tschirchiana, F.intermedia, Fragilaria capucina, G.intermedium, Gomphoema acuminatum, N.gottlandica, N.radiosa, Pinnularia acrosphaeria, P.gibba, Surirella elegans, Synedra affins, Cymbella hustedii, Surirella tenera. Out of 24 diatom species, 2 site specific diatom species were identified at site2 i.e. G. intermedium and Synedra affins.

At site3, 24 diatoms were identified such as Amphora ovalis ,A.rugosa, A.venta, C.cymbiformis, C.placentula var. lineate, Cocconeis pediculus, Craticula halophila, Cyclotella operculata, Cymatopleura solea, Diatoma vulgaris, E. tschirchiana, F.intermedia, Fragilaria capucina, G.intermedium, Gomphoema acuminatum, N.gottlandica, N.radiosa, Pinnularia acrosphaeria, P.gibba, Surirella elegans, Synedra affins, Cymbella hustedii, Surirella tenera. Out of 24 diatom species, 2 site specific diatom species were identified at site 3.i. e. Pinnularia acrosphaeria \& P.gibba.

At site4, 27 diatom species were identified such as Aulacoseira granulate, Amphora ovalis, Amphora rugosa, A.veneta, C.turgid, Cyclotella kutzingiana, Cyclotella operculata, C. meneghiniana, Cymbella affinis, Cymbella hustedii, Epithemia sorex, Eunotia alpine, F.intermedia, G.constrictum, G.intermidium, G.spheroporum, Melosira distans, Melosira granulate, N.denticula, N.radiosa. N.sinuata, N.subtilis, P.acrosphaeria, P.gibba, Pinnularia interrupta, Rhopalodia brebissonii,N.chandolensis. Out of 27 diatoms, 3 site specific diatoms were identified at site i .e. Pinnularia interrupta, Rhopalodia brebissonii \& N.chandolensis.

The present study is concluded that diatom study can be useful for medico-legal purposes such as in case of unclaimed body related to doubtful drowning/dumping cases as well as in site correlation of doubtful cases.

\section{References}

[1]. Hasle,G.R.; Syvertsen E.E. and Tomas, C.R(1997) Marine Diatoms. Identifying Marine Diatoms and Dinoflagellates. Academic press. pp 5-385.

[2]. Ludes, B., Coste M., Tracqui, A., and Mangin, P., (1996) Contivuous River Monitoring of Diatoms in The Diagnosis of Drowning. Journal of Forensic Science; 41(3): 425-28.

[3]. Metzeltin,D., Lange-Bertalot, H. \& Garcia-Rodriguez, F. (2005) Diatoms of Uruguay Taxonomy- Biography-Diversity. Iconographia Diatomologica.15: p.726.

[4]. Tayalor,J.C.;Harding,W.R.and Archibald,C.G.M. (2007) A methods manual for the collection, preparation and analysis of diatom samples, Republic of south Africa, volume 1, pp.25-35.

[5]. Tiwari, Ashesh and Chauhan S.V.S. (2006). Seasonal Phytoplanktonic diversity of Yamuna. Journal Enviromental Biology.27:35-38. 